\title{
Monilinia spp. Causing Brown Rot of Stone Fruit in Serbia
}

Jovana Hrustić, Laboratory of Applied Phytopathology, Institute of Pesticides and Environmental Protection, Banatska 31 b, 11080 Belgrade, Serbia; Goran Delibašić and Ivana Stanković, Institute of Plant Protection, Department of Phytopathology, University of Belgrade-Faculty of Agriculture, Nemanjina 6, 11080 Belgrade, Serbia; Mila Grahovac, University of Novi Sad-Faculty of Agriculture, Trg Dositeja Obradovića 8, 21000 Novi Sad, Serbia; Branka Krstić and Aleksandra Bulajić, Institute of Plant Protection, Department of Phytopathology, University of Belgrade-Faculty of Agriculture; and Brankica Tanović, Laboratory of Applied Phytopathology, Institute of Pesticides and Environmental Protection

\begin{abstract}
Hrustić, J., Delibašić, G., Stanković, I., Grahovac, M., Krstić, B., Bulajić, A., and Tanović, B. 2015. Monilinia spp. causing brown rot of stone fruit in Serbia. Plant Dis. 99:709-717.

Brown rot is one of the most important pre- and postharvest fungal diseases of stone fruit worldwide. In Serbia, where production of stone fruit is economically important, Monilinia laxa and M. fructigena are widely distributed. In surveys from 2011 to 2013, 288 isolates of Monilinia spp. were collected from 131 localities in 16 districts and from six hosts in Serbia. Using multiplex polymerase chain reaction, phylogenetic analysis, and morphological characterization, three species of Monilinia were identified as the causal agents of brown rot of stone

fruit: M. laxa ( $89 \%$ of isolates), M. fructigena (3\%), and M. fructicola (8\%). In 2011, M. fructicola was reported for the first time on stone fruit in Serbia, with only one isolate detected. More isolates of M. fructicola were detected in 2012 ( 2 isolates) and 2013 (20 isolates). The presence of $M$. fructicola, as well as its increased frequency of detection during the survey, may indicate a change in the population structure of these pathogens, which could have an important impact on brown rot disease management in Serbia.
\end{abstract}

Brown rot is one of the most important pre- and postharvest fungal diseases of stone fruit (Prunus spp.), with a worldwide distribution in all major fruit-growing areas. Under favorable weather conditions, it can cause severe losses in fruit production (31). Three Monilinia spp. that cause brown rot are economically important on stone fruit: Monilinia fructigena Honey, M. laxa (Aderh. \& Ruhland) Honey, and M. fructicola (G. Winter) Honey $(4,31)$.

Occurrence and distribution of Monilinia spp. differs significantly worldwide. M. laxa and $M$. fructigena are the primary species causing brown rot of stone fruit in Europe (5), whereas M. fructicola is widespread in stone fruit grown in the Americas and some parts of Africa and Asia (4). In Europe, M. fructigena causes preharvest and storage fruit rot of pome fruit (1) whereas, in the United States and Australia, it is a quarantine pathogen $(29,50)$. In contrast, $M$. laxa is more economically important on stone fruit and almond (Prunus dulcis), causing mainly blossom and twig blight (4), although it has also been detected on pome fruit (26). Finally, M. fructicola is the most destructive species causing blossom and twig blight, as well as fruit rot (11). It is classified as an A2 European and Mediterranean Plant Protection Organization quarantine organism (http://www. eppo.int/QUARANTINE/listA2.htm), and regulated in Annex IV, Part A, Section I of Council Directive 2000/29/EC4. However, over the last 10 years, this species has been detected in several European countries. For example, recent reports of this pathogen came from France (28), Hungary (34), the Czech Republic (8), Italy (33), Spain (7), Switzerland (3,15), Slovenia (25), Slovakia (32), Germany (30), Poland (37), and Serbia $(17,46)$. Although several reports on the occurrence of $M$. polystroma have been published $(35,37,45,51)$, its economic impact and significance is still to be established.

Monilinia spp. are reportedly able to infect fruit of their host plants only through wounds $(16,41,44,49)$. There are a few reports of $M$. fructicola and $M$. laxa infecting intact fruit

Corresponding author: B. Tanović; E-mail: brankica.tanovic@pesting.org.rs Accepted for publication 23 December 2014.

http://dx.doi.org/10.1094/PDIS-07-14-0732-RE

(C) 2015 The American Phytopathological Society
$(38,41)$ but this important epidemiological issue still needs to be clarified.

Stone fruit species are by far the most important for total fruit production in Serbia in terms of number of fruit trees and quantity of produced fruit (27), with plum being the most important. Total annual plum production amounted to over 500,000 tons in the last five years, which places Serbia among the three top producers in the world and the first in Europe (9). However, plum and other stone fruit are severely affected by brown rot every year, resulting in significant losses (2). M. laxa and $M$. fructigena are widely distributed (2), with first reports of these fungi in Serbia and their significance originating from the middle of the 20th century (40). Both pathogens appear on stone fruit every year, causing high yield losses when rain coincides with bloom or fruit ripening. As a consequence of blossom blight and fruit rot, losses in stone fruit production are estimated to be up to $100 \%$ (2). In 2011, M. fructicola, a pest on the 1A part I list of quarantine pest organisms in Serbia, was detected on stored apple and nectarine fruit $(17,46)$. The recent discovery of $M$. fructicola and its potential to develop fungicide resistance $(23,24)$, suggests possible changes in population structure of brown rot fungi in Serbia that could affect stone fruit production. Therefore, the aims of this study were to (i) identify the Monilinia spp. occurring in six of the most commonly grown stone fruit species in Serbia using conventional morphological and molecular methods; (ii) determine the relative abundance of each Monilinia sp. for each stone fruit crop; and (iii) characterize selected isolates in terms of virulence, growth rate, sporulation ability, and other morphological and molecular features.

\section{Materials and Methods}

Surveys. In order to determine the presence and distribution of Monilinia spp. on stone fruit in Serbia, surveys were carried out from 2010 to 2013. Samples of mummified fruit, infected twigs, and rotted fruit of apricot $(P$. armeniaca), peach $(P$. persica), nectarine $(P$. persica var. nectarina), plum ( $P$. domestica), sweet cherry ( $P$. avium), and sour cherry ( $P$. cerasus) were collected. Two to five samples were collected from each of 131 commercial orchards in 16 administrative districts of Serbia, depending on orchard size ( 0.2 to $2 \mathrm{ha}$ ), tree age (5 to 10 years), and presence and incidence of symptoms resembling those caused by Monilinia spp. In addition, some samples were collected from green markets and house yards. 
Fungal isolation. After collection, symptomatic plant samples were individually packed in paper bags, marked, and transported to the Laboratory for Applied Phytopathology at the Institute of Pesticides and Environmental Protection in Belgrade, where they were examined further. Plant samples were surface disinfected for 2 min with a commercial bleach solution ( $0.5 \%$ sodium hypochlorite), and small pieces $\left(2\right.$ to $3 \mathrm{~mm}^{2}$ ) from the border of healthy and diseased tissue from each sample were aseptically excised and placed onto the surface of potato dextrose agar (PDA; $200 \mathrm{~g}$ of potato, $20 \mathrm{~g}$ of dextrose, $17 \mathrm{~g}$ of agar, and 1 liter of $\mathrm{H}_{2} \mathrm{O}$ ). The plates were incubated at $24^{\circ} \mathrm{C}$ in

Table 1. Isolates of Monilinia spp. identified in this study and retrieved from the GenBank database, affected host plant, and GenBank accession numbers

\begin{tabular}{|c|c|c|c|}
\hline Species, isolate & Host & Location & GenBank accession number \\
\hline \multicolumn{4}{|l|}{$\overline{\text { Monilinia laxa }}$} \\
\hline BPČO & Peach & Serbia & KC515383y \\
\hline BPZK & Peach & Serbia & KC544793y \\
\hline KPGG & Apricot & Serbia & KC544794y \\
\hline KPGO & Apricot & Serbia & KC544795y \\
\hline NPSV & Nectarine & Serbia & KC544796y \\
\hline NPVI & Nectarine & Serbia & KC544797y \\
\hline ŠPIV & Plum & Serbia & KC544798y \\
\hline TPLČ & Sweet cherry & Serbia & KC544800y \\
\hline TPRŠ & Sweet cherry & Serbia & KC544801y \\
\hline VPJR & Sour cherry & Serbia & KC544802y \\
\hline VPSV & Sour cherry & Serbia & KC544803y \\
\hline MDA12 & Unknown & United States & HQ846948z \\
\hline BUL1A1 & Prunus insitita & France & $\mathrm{AF} 150676^{\mathrm{z}}$ \\
\hline Hirodai number 3272 & P. mume & Japan & $\mathrm{AB} 125612$ \\
\hline Sh675 & Plum & Chile & EU042149 \\
\hline ES14 & Unknown & Spain & EF153016 \\
\hline CBS298.31 & Unknown & United States & HQ846949z \\
\hline 1067.k & Malus domestica & Norway & $\mathrm{Z73784}$ \\
\hline Hirodai number 2646 & P. mume & Japan & AB125618 \\
\hline \multicolumn{4}{|l|}{ M. fructigena } \\
\hline BŠPBA & Plum & Serbia & KC544804y \\
\hline ŠPBA & Plum & Serbia & KC544805y \\
\hline ŠPPR & Plum & Serbia & KC544806 \\
\hline TPGO & Sweet cherry & Serbia & KC544807y \\
\hline GENA4 & Unknown & United Kingdom & HQ846945z \\
\hline $3 \mathrm{FG}$ & Cydonia oblonga & Hungary & AM937109 \\
\hline UASWS0643 & M. domestica & Switzerland & HQ166417 \\
\hline IHEM & Pear & Belgium & FJ515296 \\
\hline $40 \mathrm{FG}$ & C. oblonga & Hungary & AM937113 \\
\hline WASWS0333 & M. domestica & Switzerland & EU098121 \\
\hline W17 & Unknown & Spain & $\mathrm{EF} 207424^{\mathrm{z}}$ \\
\hline COY2M & P. institia & France & $\mathrm{AF} 150680^{\mathrm{z}}$ \\
\hline 1079.k & P. domestica & Norway & Z73781 \\
\hline \multicolumn{4}{|l|}{ M. fructicola } \\
\hline NPUD1 & Nectarine & Serbia & KC544808y \\
\hline NPUD2 & Nectarine & Serbia & KC544809y \\
\hline NPGM & Nectarine & Serbia & JX127303y \\
\hline 99.2.G5.04 & Unknown & United States & DQ314730 \\
\hline $\mathrm{Ft}$ & Unknown & France & HQ846967z \\
\hline LH01 & Red bayberry & China & AM887528 \\
\hline W1 & Unknown & Spain & $\mathrm{EF} 207420^{\mathrm{z}}$ \\
\hline Hirodai number 2636 & P. avium & Japan & AB125615 \\
\hline M1PL & Unknown & Poland & $\mathrm{JX} 312665^{\mathrm{z}}$ \\
\hline $782 . \mathrm{k}$ & P. persica & Norway & Z73777 \\
\hline M10020029 & Peach & Slovenia & GU967379z \\
\hline $\mathrm{P} 164$ & Unknown & Italy & FJ411110z \\
\hline THF-1 & Peach & China & FJ515894 \\
\hline BHY1 & Cherry & China & HQ846927z \\
\hline SLT2 & Peach & China & HQ846939z \\
\hline NE18 & Unknown & New Zealand & HQ846919z \\
\hline LVN8 & Unknown & United States & HQ846966 \\
\hline DAOM231119 & Wine grape & Canada & AY289185 \\
\hline Unknown & M. domestica & Serbia & JN176564z \\
\hline \multicolumn{4}{|l|}{ M. polystroma } \\
\hline HML3 & P. aitianli & China & GU067539z \\
\hline 2319 & Unknown & Japan & HQ856916 \\
\hline UFT & M. domestica & Hungary & AM937114 \\
\hline AP1 & M. domestica & Poland & JF820317 \\
\hline MP13 & M. domestica & Serbia & $\mathrm{JX} 315717^{\mathrm{z}}$ \\
\hline
\end{tabular}

y Sequences generated in this study.

${ }^{\mathrm{z}}$ Sequences from peer-reviewed sources. 
the dark and inspected after 3 to 5 days for gray, creamy yellow, or hazel zonate colonies with lobed or even margins, which are characteristic for Monilinia spp. Single-spore cultures were derived from each isolate and identified on the basis of their morphological and molecular features. Isolates were stored at $-80^{\circ} \mathrm{C}$ in $20 \%$ glycerol for long-term storage, and at $4^{\circ} \mathrm{C}$ on PDA slants for short-term storage.

Morphological identification and characterization of Monilinia spp. isolates. For morphological characterization, 3-mm-diameter plugs of actively growing mycelium were cut from the edge of a 4-day-old colony on PDA and subcultured on fresh PDA. After 10 days of incubation at $22^{\circ} \mathrm{C}$, colony color, colony margin appearance, rosetting pattern, sporulation, presence of concentric rings of spores, presence of black arcs (lines on substrate side of colonies), and qualitative growth rate were determined (20).

After identifying to species (see below), three representative isolates of each species from different host plants and districts of
Serbia were selected for detailed characterization based on growth rate on three media: PDA, V8 agar (200 $\mathrm{ml}$ of V8 juice, $20 \mathrm{~g}$ of agar, and 1 liter of $\mathrm{H}_{2} \mathrm{O}$ ), and MALT (500 ml of industrial malt, $17 \mathrm{~g}$ of agar, and $500 \mathrm{ml}$ of $\mathrm{H}_{2} \mathrm{O}$ ). Growth rate was calculated after 7 days of incubation at $24^{\circ} \mathrm{C}$ in darkness and expressed as millimeters per day. The mean value of three replicates was used to represent each isolate. Additionally, sporulation was quantified on MALT medium after incubation at $24^{\circ} \mathrm{C}$ in darkness. Ten-day-old cultures were flooded with $10 \mathrm{ml}$ of sterile distilled water and conidia were gently removed from the media with a glass rod. The concentration of conidia was estimated using a hemocytometer, and the mean number of conidia was calculated from three replicate cultures. Conidial size, germ tube length, and morphology were also determined for each of the nine selected isolates. The suspension of conidia was spread onto water agar (WA; $17 \mathrm{~g}$ of agar and 1 liter of $\mathrm{H}_{2} \mathrm{O}$ ) with sterile cotton swabs and incubated at $24^{\circ} \mathrm{C}$ in the dark for $18 \mathrm{~h}$. Germ tube

Table 2. Occurrence of Monilinia spp. on stone fruit in Serbia during 2010 to 2013

\begin{tabular}{|c|c|c|c|c|c|}
\hline Year, districts & Number of fields ${ }^{\mathbf{z}}$ & Number of isolates & Monilinia laxa & M. fructigena & M. fructicola \\
\hline \multicolumn{6}{|l|}{2010} \\
\hline South Bačka & 1 & 2 & 2 & 0 & 0 \\
\hline Central Banat & 1 & 1 & 1 & 0 & 0 \\
\hline Srem & 5 & 8 & 7 & 1 & 0 \\
\hline City of Belgrade & 2 & 4 & 3 & 1 & 0 \\
\hline Podunavlje & 1 & 2 & 2 & 0 & 0 \\
\hline Subtotal $=5$ & 10 & 17 & 15 & 2 & 0 \\
\hline \multicolumn{6}{|l|}{2011} \\
\hline Šumadija & 1 & 1 & 0 & 0 & 1 \\
\hline Moravica & 1 & 1 & 0 & 1 & 0 \\
\hline Jablanica & 3 & 13 & 13 & 0 & 0 \\
\hline Subtotal $=3$ & 5 & 15 & 13 & 1 & 1 \\
\hline \multicolumn{6}{|l|}{2012} \\
\hline South Bačka & 4 & 11 & 11 & 0 & 0 \\
\hline South Banat & 1 & 3 & 3 & 0 & 0 \\
\hline Srem & 13 & 22 & 22 & 0 & 0 \\
\hline City of Belgrade & 29 & 65 & 65 & 0 & 0 \\
\hline Mačva & 2 & 2 & 2 & 0 & 0 \\
\hline Podunavlje & 10 & 24 & 21 & 1 & 2 \\
\hline Braničevo & 14 & 23 & 20 & 3 & 0 \\
\hline Moravica & 7 & 20 & 19 & 1 & 0 \\
\hline Šumadija & 10 & 19 & 19 & 0 & 0 \\
\hline Zlatibor & 9 & 23 & 23 & 0 & 0 \\
\hline Rasina & 2 & 3 & 3 & 0 & 0 \\
\hline Zaječar & 1 & 1 & 1 & 0 & 0 \\
\hline Nišava & 1 & 1 & 1 & 0 & 0 \\
\hline Subtotal $=13$ & 103 & 217 & 210 & 5 & 2 \\
\hline \multicolumn{6}{|l|}{2013} \\
\hline City of Belgrade & 4 & 8 & 6 & 0 & 2 \\
\hline Kolubara & 2 & 3 & 0 & 0 & 3 \\
\hline Podunavlje & 6 & 27 & 12 & 0 & 15 \\
\hline Zlatibor & 1 & 1 & 1 & 0 & 0 \\
\hline Subtotal $=4$ & 13 & 39 & 19 & 0 & 20 \\
\hline Total $=16$ & 131 & 288 & 257 & 8 & 23 \\
\hline
\end{tabular}

$\mathrm{z}$ Two to five samples of mummified fruit, infected twigs, and rotted fruit of apricot, peach, nectarine, plum, sweet cherry, and sour cherry were collected from each of 131 commercial orchards in 16 administrative districts of Serbia, depending on orchard size, tree age, and presence and incidence of symptoms resembling those caused by Monilinia spp.

Table 3. Comparison of morphological features of Monilinia laxa, M. fructigena, and M. fructicola isolates

\begin{tabular}{lclccccc}
\hline Species & Number of isolates & Colony color & Colony shape $^{\mathbf{v}}$ & Colony margin $^{\mathbf{w}}$ & Sporulation $^{\mathbf{x}}$ & Concentric ring of spores $^{\mathbf{y}}$ & Black arcs $^{\mathbf{z}}$ \\
\hline M. laxa & 257 & Gray & - & $\mathrm{L}$ & - & - & $+/-$ \\
M. fructigena & 8 & White/Yellow & $\mathrm{R}$ & $\mathrm{E}$ & + & + & +- \\
M. fructicola & 23 & Gray & - & $\mathrm{E}$ & ++ & +- \\
\hline
\end{tabular}

v Colony shape: $\mathrm{R}=$ rosette and $-=$ not rosette.

${ }^{w}$ Colony margin: $\mathrm{L}=$ lobate and $\mathrm{E}=$ entire.

x Sporulation: $+=$ abundant and $-=$ sparse.

y Concentric ring of spores: $+=$ present and $-=$ absent.

${ }^{\mathrm{z}}$ Black arcs: $+=$ present and $-=$ absent. 
length was measured with a stage micrometer using a light microscope at $\times 100$ magnification. At minimum, 50 conidia and germ tubes were measured for each isolate. All data were analyzed by analysis of variance (ANOVA) at the 5\% probability level, with individual pairwise comparisons made using Tukey's test (39). Each experiment was performed two times, with three replicates for each isolate.

Molecular identification. Total genomic DNA was isolated from mycelia of 7-day-old cultures grown on PDA using a method described by Harrington and Wingfield (14).

Molecular identification of all 288 Monilinia spp. isolates was performed with multiplex polymerase chain reaction (PCR), using the common reverse primer MO368-5, which is specific for Monilinia spp., and three species-specific forward primers-MO368-8R for M. fructigena and M. polystroma, MO368-10R for M. fructicola, and Laxa-R2 for M. laxa (6) - in order to amplify a noncoding region of Monilinia spp. with unknown function.

The PCR mix contained $12.5 \mu \mathrm{l}$ of $2 \times$ Master mix with $2 \mathrm{mM}$ $\mathrm{MgCl}_{2}$ (Fermentas Life Sciences $\mathrm{GmbH}$, Lithuania), $1 \mu \mathrm{l}$ of $0.2 \mu \mathrm{M}$ each primer, $1 \mu \mathrm{l}$ of template DNA, and moleculargrade water up to a final volume of $25 \mu \mathrm{l}$. PCRs were performed in an Eppendorf Master Cycler (Eppendorf, Germany) with the following reaction conditions: an initial denaturation at $95^{\circ} \mathrm{C}$ for $2 \mathrm{~min}$; followed by 35 cycles of $95^{\circ} \mathrm{C}$ for $15 \mathrm{~s}, 60^{\circ} \mathrm{C}$ for $15 \mathrm{~s}$, and $72^{\circ} \mathrm{C}$ for $1 \mathrm{~min}$; and a final extension at $72^{\circ} \mathrm{C}$ for $3 \mathrm{~min}$. Negative controls were included by replacing template DNA with molecular-grade water. The PCR products were separated by electrophoresis in $2 \%$ agarose gels run in $1 \times$ Tris-borate EDTA buffer at $100 \mathrm{~V}$ constant voltage. The gels were stained with ethidium bromide and the products were visualized and photographed under UV light.

Sequencing of ribosomal DNA internal transcribed spacer region. The identity of a subset of 18 Monilinia spp. isolates was further confirmed by amplification and sequencing of the internal transcribed spacer (ITS) region of ribosomal DNA (rDNA) using primers ITS1 and ITS4 (48) and the same reaction mixture as described above. PCR amplifications were performed with an initial denaturation for $90 \mathrm{~s}$ at $94^{\circ} \mathrm{C}$, followed by 29 cycles consisting of a denaturation step for $30 \mathrm{~s}$ at $94^{\circ} \mathrm{C}$, primer annealing for $30 \mathrm{~s}$ at $55^{\circ} \mathrm{C}$, and extension for $30 \mathrm{~s}$ at $72^{\circ} \mathrm{C}$. The final extension step was performed at $72^{\circ} \mathrm{C}$ for $9 \min 30 \mathrm{~s}(48)$.

Amplified products were purified using the mi-PCR Purification Kit (Metabion International, Germany), according to the manufacturer's instructions, and sequenced directly on automated equipment (Macrogen Inc., Korea) in both directions using the same primers as for amplification. For each isolate, the consensus sequence covering the partial rDNA-ITS region was reconstructed using the ClustalW program (43) and deposited in GenBank (http:// www.ncbi.nlm.nih.gov/BLAST/). Sequences of Serbian Monilinia spp. isolates were compared with the respective sequences available in the GenBank using the ClustalW program (43) and MEGA5 software (42).

Phylogenetic analysis. A phylogenetic tree was reconstructed based on 18 ITS sequences generated in this study and 38 sequences representing $M$. fructicola, M. laxa, $M$. fructigena, and $M$. polystroma isolates from different hosts and geographic origins retrieved from
GenBank (Table 1) using the Maximum Parsimony algorithm implemented in MEGA5. The tree was evaluated with 1,000 bootstrap replications to test clade stability, and bootstrap values $<50 \%$ were omitted. Sequences of both Botryotinia fuckeliana (GenBank accession number HQ846943) and Sclerotinia sclerotiorum (HQ846942) were used as outgroup reference species.

Pathogenicity test and reisolation. Pathogenicity of all isolates of M. laxa $(n=257), M$. fructigena $(n=8)$, and M. fructicola $(n=23)$ was confirmed on wounded fruit of the originating host plant. The fruit were surface disinfected with $0.5 \% \mathrm{NaClO}$ for $5 \mathrm{~min}$, rinsed three times with sterile-distilled water, and air dried. Each fruit was wounded with a carpenter nail $(4 \mathrm{~mm}$ in diameter and $3 \mathrm{~mm}$ in depth), and a mycelial plug ( $3 \mathrm{~mm}$ in diameter) from the margin of a 6-day-old colony grown on PDA was placed on each wound. Five fruit were used for each isolate. Fruit inoculated with sterile PDA plugs served as a negative control. Inoculated fruit were incubated for 3 days in randomly arranged separate plastic containers at $24^{\circ} \mathrm{C}$ and $97 \%$ relative humidity (RH) in darkness. Inoculated fruit were inspected daily for the occurrence of brown rot symptoms. After the appearance of disease symptoms in the inoculated fruit, the pathogen was reisolated on PDA. Then, the morphological features of the isolated fungi were compared and matched with the original ones used for inoculation. The experiment was repeated twice.

Pathogenicity on nonwounded fruit. Pathogenicity of three selected representative isolates (one $M$. fructigena, one $M$. laxa, and one $M$. fructicola) was tested on nonwounded mature fruit of six stone fruit species: nectarine, peach, apricot, sour cherry, sweet cherry, and plum. Mycelial plugs of all three isolates, prepared using the previously described procedure, were placed upside down on the intact cuticle of the surface-sterilized fruit. For each isolate and each fruit species, five fruit were used. Fruit inoculated with sterile PDA plugs served as a negative control. Occurrence of brown rot symptoms and sporulation was observed after incubation at $24^{\circ} \mathrm{C}$ and 97\% RH in darkness for 7 days.

Virulence to different host plants. The virulence of selected representative isolates of $M$. fructigena (four isolates), M. laxa (four isolates), and M. fructicola (one isolate) originating from different fruit species was tested on mature wounded fruit of the originating host plant as well as other stone fruit, including nectarine, peach, apricot, and plum. Pathogenicity tests were conducted as described above. In all, 5 fruit in three replicates (total of 15 fruit) for each host plant and isolate were used. The lesion size was measured 3 days postinoculation, and the values [(width + length)/2] were calculated. The experiment was repeated twice and results were analyzed for effects of isolate in each fruit species separately by ANOVA at the 5\% probability level, with individual pairwise comparisons made using Tukey's test (39).

\section{Results}

Presence and distribution of brown rot fungi in Serbia. During the 4-year survey, infected plant parts showing characteristic symptoms were collected from 131 fields (Table 2). In total, 288 isolates resembling Monilinia spp. were recovered: 232 isolates from fresh fruit, 45 from mummified fruit, and 11 from twigs. M. laxa was by far the most frequently isolated species from mummified fruit and

Table 4. Colony growth rate and sporulation of Monilinia laxa, M. fructigena, and M. fructicola isolates ${ }^{\mathrm{y}}$

\begin{tabular}{|c|c|c|c|c|c|c|}
\hline \multirow[b]{3}{*}{ Species } & \multicolumn{6}{|c|}{ Colony growth rate $(\mathrm{mm} / \mathrm{day})$ on $^{\mathrm{z}}$} \\
\hline & \multicolumn{2}{|c|}{ PDA } & \multicolumn{2}{|c|}{ V8 juice agar } & \multicolumn{2}{|c|}{ MALT } \\
\hline & Mean \pm SD & Range & Mean \pm SD & Range & Mean \pm SD & Range \\
\hline M. laxa & $8.7 \pm 0.4 b$ & $8.0-9.1$ & $6.9 \pm 0.2 \mathrm{a}$ & $6.6-7.1$ & $12.0 \pm 0.2 \mathrm{a}$ & $11.9-12.3$ \\
\hline M. fructigena & $2.6 \pm 0.4 \mathrm{c}$ & $2.3-3.3$ & $3.7 \pm 0.2 b$ & $3.4-4.0$ & $11.9 \pm 0.2 \mathrm{a}$ & $11.4-12.1$ \\
\hline \multirow[t]{2}{*}{ M. fructicola } & $11.4 \pm 1.0 \mathrm{a}$ & $10.1-12.4$ & $2.9 \pm 0.4 \mathrm{c}$ & $2.6-3.6$ & $8.8 \pm 0.7 \mathrm{~b}$ & $8.1-10.3$ \\
\hline & & & & & \multicolumn{2}{|c|}{ (continued on next page) } \\
\hline
\end{tabular}

\footnotetext{
y The same letter within the column indicates that the difference is not significant. Mean value \pm standard deviation (SD).

${ }^{\mathrm{z}} \mathrm{PDA}=$ potato dextrose agar and MALT $=$ malt extract agar.
} 
twigs. M. laxa occurred in all but the Kolubara district, M. fructigena was found in 5 districts, and M. fructicola was detected in 4 of the 16 sampled districts. All isolates were identified using both morphological characteristics and molecular methods.

Morphological identification and characterization of Monilinia spp. isolates. On PDA, 257 isolates that were light to dark gray with lobed margins and no sporulation were identified as M. laxa. Eight isolates with cream to yellow colonies, rare sporulation, and entire margins were identified as $M$. fructigena. Twenty-three of 288 isolates that developed hazel-colored zonate colonies with more or less even margins and abundant sporulation, and concentric rings of spores on the surface were identified as M. fructicola (Table 3). Of 257 isolates of M. laxa, 44 originated from mummified fruit, 202 from fresh fruit, and 11 from twigs. A total of 6 isolates of $M$. fructigena and 18 isolates of $M$. laxa developed black arcs on the undersurface of the culture; none of the isolates of M. fructicola exhibited this feature. One of eight $M$. fructigena isolates was derived from mummified and seven from fresh fruit. All isolates of M. fructicola originated from fresh fruit.

In-depth study of the nine representative isolates of Monilinia spp. show that growth rates on PDA, MALT, and V8 juice medium differed significantly among isolates and species as well as isolates from the same species $(P<0.05$; Table 4$)$. On PDA, $M$. fructicola had the highest growth rate (10.1 to $12.4 \mathrm{~mm} /$ day) and $M$. fructigena had the lowest ( 2.3 to $3.3 \mathrm{~mm} /$ day). On MALT medium, M. fructigena (11.4 to $12.1 \mathrm{~mm} /$ day) and $M$. laxa (11.9 to $12.3 \mathrm{~mm} /$ day) grew significantly $(P<0.05)$ faster than $M$. fructicola $(8.1$ to $10.3 \mathrm{~mm} /$ day $)$. In general, growth rates of $M$. laxa and $M$. fructigena isolates were faster on MALT medium compared with PDA and V8 juice, whereas growth rates of $M$. fructicola was greatest on PDA medium.

The conidia of $M$. fructigena were $22.0 \mu \mathrm{m}$ long (20.0 to $25.0 \mu \mathrm{m}$ ) and $13.0 \mu \mathrm{m}$ wide (10.0 to $15.0 \mu \mathrm{m})$, M. laxa were 11.2 by $8.2 \mu \mathrm{m}$ (7.5 to 12.5 by 5.0 to 10.0), and M. fructicola were 16.0 by $10.7 \mu \mathrm{m}$ (12.5 to 17.5 by 7.5 to 12.5 ). Conidia of $M$. fructigena germinated into multiple germ tubes, whereas $M$. laxa and $M$. fructicola consistently germinated into one germ tube. M. laxa was also distinguished from M. fructigena and M. fructicola by the characteristic short-distance germ tube elongation from the conidium to the first germ tube branch (less than $60 \mu \mathrm{m}$ ). Germ tube elongation for $M$. fructicola and M. fructigena was 365 and $197 \mu \mathrm{m}$, respectively. The most abundant sporulation was recorded for M. fructicola $\left(3.0 \times 10^{4}\right)$, followed by M. fructigena and M. laxa $\left(1.5 \times 10^{4}\right.$ and $0.3 \times 10^{4}$, respectively) (Table 4).

PCR identification. Further confirmation of M. laxa, M. fructigena, and M. fructicola on stone fruit in Serbia was done by using multiplex PCR. All primers were able to amplify one clear band of predicted size of 535 bp for M. fructicola, 402 bp for M. fructigena, and $352 \mathrm{bp}$ for $M$. laxa, providing preliminary identification of 257 isolates as M. laxa, 8 isolates as M. fructigena, and 23 isolates as $M$. fructicola.

Sequence analysis and phylogeny of brown rot fungi. BLAST analysis showed that the ITS sequence of 11 Serbian M. laxa isolates had $100 \%$ nucleotide identity with GenBank M. laxa sequences, and sequences of $4 M$. fructigena isolates had $100 \%$ nucleotide identity to $M$. fructigena from other parts of the world. Sequences of three Serbian M. fructicola isolates were identical to each other and to 17 isolates of M. fructicola from GenBank originating from different parts of the world, including 4 from Europe (FJ411109, FJ411110, GU967379, and JN176564). Comparison of ITS sequences revealed $100 \%$ nucleotide identity among isolates of the same species, except for the sequence of VPSV (M. laxa) isolate derived from sour cherry sampled in Slankamenački Vinogradi, which showed difference in one nucleotide ( $99.8 \%$ identity) from other $M$. laxa isolates obtained in this study.

A maximum parsimony tree, reconstructed using the ITS sequence of 54 Monilinia isolates, revealed the presence of two main clusters, each containing two well-supported disjunct groups (Fig. 1). In one clade, isolates of $M$. laxa originating from the Americas (United States and Chile), Asia (Japan), and Europe (France, Norway, and Spain) and 11 Serbian M. laxa isolates were present in one group, and 3 M. fructicola isolates from Serbia and 16 from Japan, New Zealand, the United States, Canada, China, Spain, Norway, Slovenia, Poland, France, Italy, and Serbia (from stored apple fruit JN176564) were present in the other group. In the second clade, M. polystroma isolates from Hungary, Poland, Serbia, and Asia occurred in one group, and four isolates of $M$. fructigena from Serbia obtained in this study (BŠPBA, ŠPBA, ŠPPR, and TPGO) together with nine isolates of M. fructigena from Europe (Switzerland, Norway, Belgium, the United Kingdom, Hungary, Spain, and France) were in the second group.

Species composition of brown rot fungi in Serbia. Based on morphological characteristics, molecular identification, and ITS sequence analysis, $89 \%$ of isolates obtained in this study were M. laxa, $3 \%$ were M. fructigena, and $8 \%$ were $M$. fructicola. M. fructicola was isolated in the second ( 1 isolate), third ( 2 isolates), and fourth (20 isolates) year of the survey. M. laxa was detected in all years, on all hosts, and in all surveyed districts of Serbia, and it was isolated from all plant parts studied. Seven of eight $M$. fructigena isolates were found on fresh fruit of plum and sour and sweet cherry from central parts of the country (Belgrade City, Podunavlje, Braničevo, Sumadija, and Moravica). In addition, one isolate of $M$. fructigena was derived from mummified plum fruit originating from the Moravica region in central Serbia. M. fructicola, a quarantine pathogen in Serbia, was detected on fresh fruit of nectarine, apricot, plum, and peach in four regions in central Serbia (Šumadija region, Podunavlje, Kolubara, and Belgrade City) (Table 2).

Pathogenicity test and reisolation. After 3 days of incubation on inoculated fruit, all Monilinia spp. isolates caused brown rot symptoms on their respective host species. Koch's postulates were fulfilled by successful reisolation of the pathogen from all inoculated fruit. Colony morphology of the original and recovered isolates was identical.

Pathogenicity on nonwounded fruit. Artificial inoculation of nonwounded mature fruit of nectarine, peach, apricot, sour cherry, sweet cherry, and plum with selected isolates of all three Monilinia spp. resulted in the development of brown rot symptoms in all fruit-isolate combinations. However, sporulation on inoculated fruit was different among Monilinia spp.; M. laxa and M. fructigena isolates did not sporulate on any of the hosts, whereas $M$. fructicola produced intense sporulation on all inoculated fruit.

Virulence to different host plants. After 3 days of incubation, all inoculated wounded fruit of four stone fruit species tested showed typical brown rot symptoms, whereas none of the fruit inoculated with sterile agar plugs developed symptoms. Artificial inoculation

Table 4. (continued from previous page)

\begin{tabular}{|c|c|c|c|c|c|}
\hline \multicolumn{2}{|c|}{ Conidial size $(\mu \mathrm{m})$} & \multicolumn{2}{|c|}{ Germ tube length $(\mu \mathrm{m})$} & \multirow[b]{2}{*}{ Number of conidia $\left(\mathrm{cm}^{2}\right)$} & \multirow[b]{2}{*}{ Germination (\%) } \\
\hline Mean & Range & Mean & Range & & \\
\hline $11.2 \times 8.2$ & $7.5-12.5 \times 5-10$ & 40 & $20-70$ & $0.3 \times 10^{4} \mathrm{c}$ & 88.0 \\
\hline $22.0 \times 13.0$ & $20-25 \times 10-15$ & 197 & $70-800$ & $1.5 \times 10^{4} \mathrm{~b}$ & 83.3 \\
\hline $16.0 \times 10.7$ & $12.5-17.5 \times 7.5-12.5$ & 365 & $210-600$ & $3.0 \times 10^{4} \mathrm{a}$ & 88.7 \\
\hline
\end{tabular}


of wounded stone fruit revealed significant differences in virulence among isolates of Monilinia spp., as well as among isolates of the same species $(P<0.01)$. M. fructigena was most destructive on peach and nectarine fruit, whereas two different $M$. laxa isolates (BMLE and VGRSE) were most virulent on plum and apricot, regardless the original host of the isolate that was used for inoculation. Thus, on nectarine and peach fruit, the highest virulence was recorded for the isolate of $M$. fructigena originated from plum (ŠPPR) whereas, on plum fruit, the largest necrotic zone was caused by the M. laxa isolate from peach (BMLE). On apricot fruit, isolates of M. laxa caused

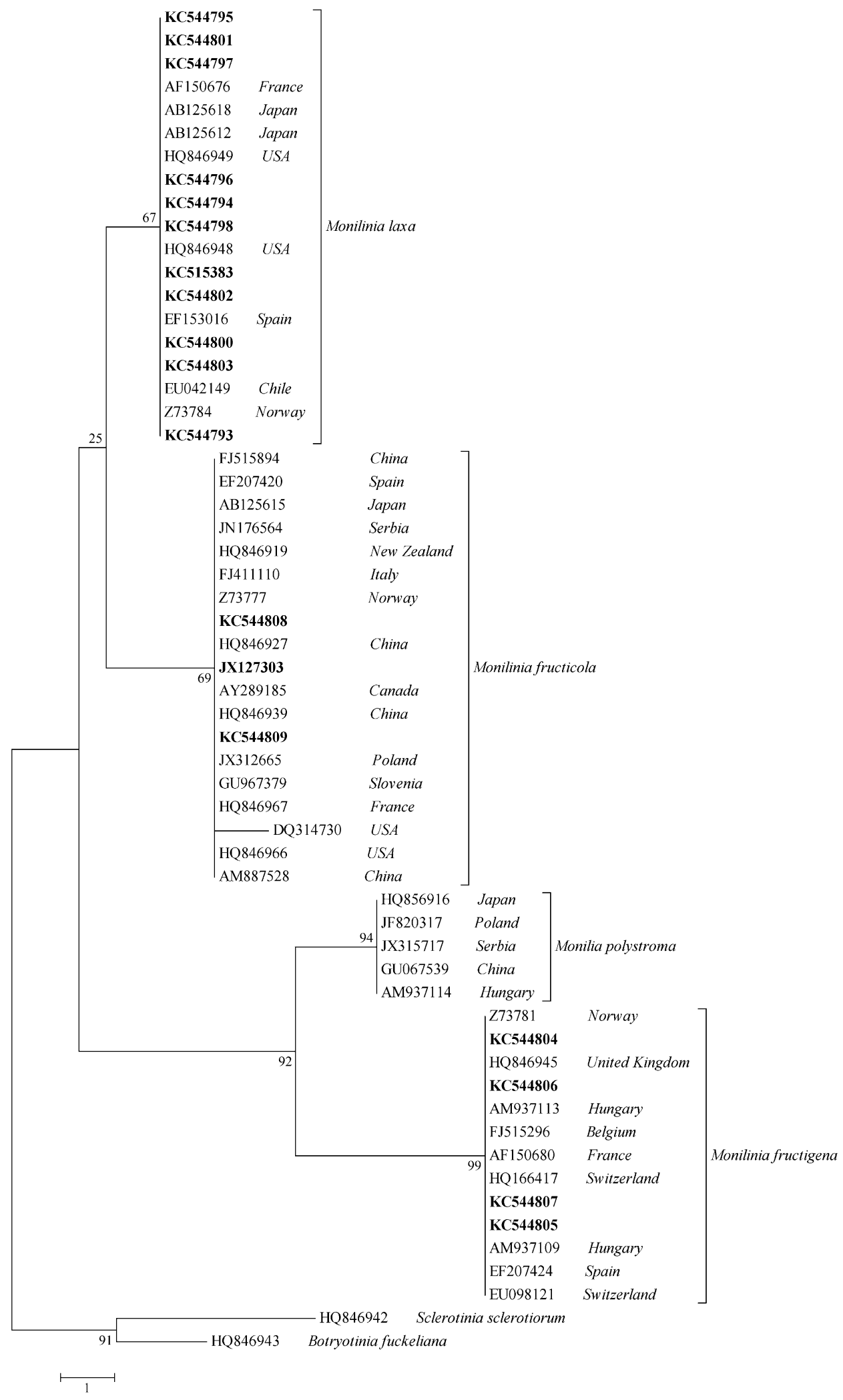

Fig. 1. Phylogenetic relationships among Monilinia laxa, M. fructigena, and M. fructicola isolates obtained from DNA isolated from stone fruit from Serbia, based on nuclear ribosomal DNA internal transcribed spacer (ITS) region. The tree was constructed using the maximum parsimony algorithm, with the Botryotinia fuckeliana and Sclerotinia sclerotiorum ITS sequences as outgroup. Bootstrap values are shown above or below branches. The numbers near each branch represent percentages out of 1,000 bootstrap replications. Bold accession number were sequenced in this study and others were retrieved from GenBank. 
the largest (VGRSE) and smallest (ŠPSV) necrotic zones. None of the isolates, however, originated from apricot (Fig. 2).

\section{Discussion}

Until 2011, the general belief was that M. laxa and M. fructigena were widely distributed on stone fruit in Serbia and the only fungi causing brown rot. In 2011, M. fructicola was detected for the first time in Serbia, first on apple (46) and later in the same year on nectarine (18). Significant changes in population structure of Monilinia spp. were recorded in California (23), and in some European Union countries after the introduction of $M$. fructicola $(19,36,37)$. Studies on the diversity of Monilinia spp. on stone fruit in Serbia were undertaken because changes in species prevalence and distribution are expected to influence disease epidemiology, cause greater yield losses, change efficacy of fungicides, and raise the cost of control measures.

In most European countries, $M$. laxa and $M$. fructigena are the predominant species $(26,36,37)$. Poniatowska et al. (37) reported that $M$. fructigena was the most frequently isolated species in Poland (60\%), followed by M. laxa (26\%) and M. fructicola and M. polystroma (4\%). Recently, M. fructicola was detected in Hungary on peach fruit imported from Italy and Spain $(34,36)$. In the 1950s, M. laxa was the most common brown rot species in California. However, according to Michailides et al. (23), when benomyl resistance in $M$. fructicola increased, the later species became the most prevalent (22). M. fructicola is also the most prevalent brown rot fungus on stone fruit in China (93\%), followed by M. fructigena (5\%), M. laxa (2\%), and $M$. polystroma $(<1 \%)(50)$. Our research suggests that a similar situation occurs with Monilinia spp. in Serbia. Among 288 isolates from 131 different locations and six hosts, three species of Monilinia were found, indicating a more complex species composition than was previously recognized. Among the Monilinia isolates recovered from necrotic twigs, rotted, and mummified fruit collected in stone fruit orchards in Serbia from 2010 to 2012, M. laxa was by far the most frequently isolated species $(96 \%)$ compared with $M$. fructigena (3\%), although previous data indicated its prevalence on stone fruit during the 1950s (40). Stojanović and Kostić (40) detected only M. fructigena and M. laxa at 59 and $41 \%$ incidence, respectively. Our data showed that, during a 50-year period, the population structure of Monilinia has changed significantly, with M. laxa becoming the most prevalent species in Serbia. However, in 2011, the presence of $M$. fructicola on stone fruit in Serbia was reported for the first time, with only one isolate detected (17). In further investigations, more isolates of M. fructicola were detected (2 in 2012 and 20 in 2013). The presence of M. fructicola, as well as its apparent increased detection during the survey, indicates that a change in the population structure of these pathogens may be occurring. This change could have an important impact on disease management, making it more difficult.

Accurate and timely identification and early detection is the cornerstone of successful disease management. Identification of Monilinia spp. used to be based on the host plant, symptoms, morphology, and cultural features (4). All three Monilinia spp. cause similar brown rot symptoms on their hosts and cannot be reliably distinguished based on symptoms alone. Therefore, precise identification to the species level is possible by combining different identification methods. Among recommended methods, morphological identification based on colony characters on PDA according to the key described by Lane (20) is the simplest and the most convenient way, which was confirmed by these studies. However, morphological characterization is time consuming, affected by environmental conditions, and not always reliable for accurate species discrimination $(21,36)$. For these reasons, molecular methods have been developed to accurately identify Monilinia spp. $(6,10,12,18,44)$; thus, primers and protocols described by Còté et al. (6) were tested in this research. The methods proved to be precise, fast, reliable, and easy to follow in a single-tube reaction. Using this protocol, the morphological identification of all 288 isolates of three Monilinia spp. was successfully confirmed.

For Monilinia spp., the ITS region is highly conserved and there are only a few nucleotide differences among these species (21). Phylogenetic analysis using this region of 18 isolates confirmed the close relationship between $M$. fructicola and $M$. laxa, and between $M$. fructigena and $M$. polystroma, as reported by Poniatowska et al. (37). As expected, all M. laxa and M. fructicola isolates clustered into main group I, whereas $M$. polystroma and $M$. fructigena isolates were clustered into main group II. The results also showed that the isolates of M. laxa, $M$. fructigena, and $M$. fructicola from Serbia did not differ from respective isolates originating worldwide.

There are conflicting opinions in the literature regarding modes of fruit penetration and infection establishment of Monilinia spp. Gibert et al. (13) and Sződi et al. (41) stated that M. laxa can infect fruit through wounds only. The results obtained by Sződi et al. (41) show that only $M$. fructicola is capable of infecting nonwounded fruit, whereas Holb (16) and Xu and Robinson (49) reported that M. fructicola can penetrate the fruit only through wounds. In contrast, Rungjindamai et al. (38) established that $M$. fructicola and M. laxa can infect both wounded and nonwounded fruit, whereas $M$. fructigena can infect

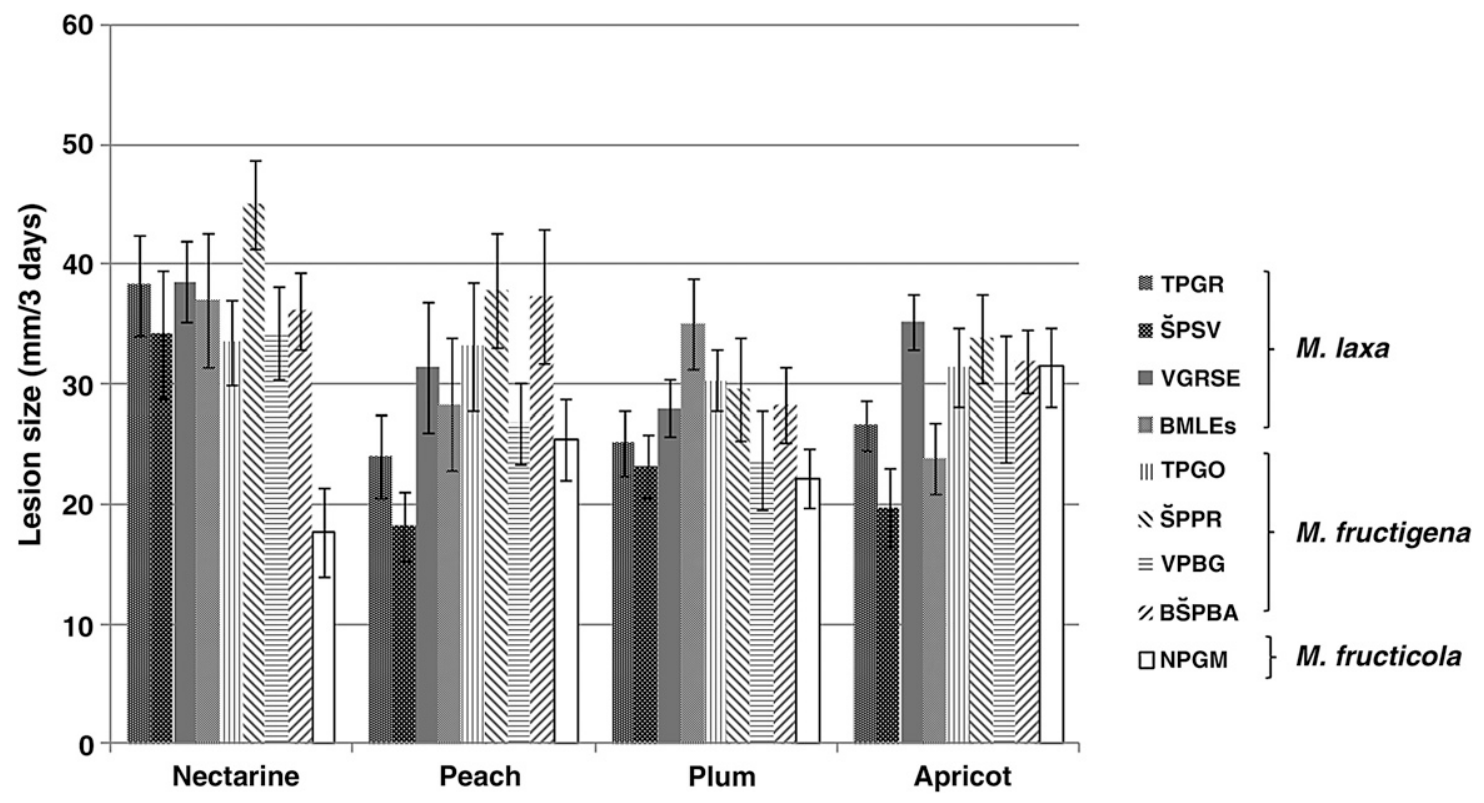

Fig. 2. Virulence of Monilinia laxa, M. fructigena, and M. fructicola on fruit of different stone fruit species. 
only wounded fruit. Our study showed that all isolates of all three Monilinia spp. from Serbia were capable of infecting both wounded and nonwounded fruit. In addition, virulence of Monilinia spp. isolates on wounded fruit from different hosts showed that the origin of the isolate regarding host did not influence the level of isolate's virulence. Therefore, it can be expected that all investigated Monilinia spp. can spread from one host to the other easily, which should be taken into consideration during orchard establishment

Using the multiplex PCR technique, phylogenetic analysis, and morphological characterization, three species (M. laxa, M. fructigena, and $M$. fructicola) were identified as the causal agents of brown rot of stone fruit in Serbia. This research revealed that M. laxa is the prevalent species (89\%) and that it has almost completely displaced M. fructigena (3\%). However, after the introduction and establishment of $M$. fructicola, this situation may change. The potential for M. fructicola to become the prevalent brown rot pathogen has been proven in California, where it partly displaced $M$. laxa in pruneand apricot-growing areas during the last several decades $(22,23)$. Based on the limited number of M. fructicola isolates obtained in this study, it is difficult to estimate a possible impact of this new species on fruit production in Serbia. The risk of its spreading may be high because it is associated mainly with its adaptive capacity, widespread presence of susceptible host plants, and human activity. M. fructicola also exhibits higher growth and sporulation capability as well as a higher level of virulence in comparison with M. laxa and M. fructigena (47), and may be able to displace them in the orchards. Additionally, international trade can be responsible for spreading $M$. fructicola (19), raising the level of concern. Stone fruit imported into Switzerland from the United States and France tested positive for M. fructicola (3), and peach fruit imported into Hungary from Spain and Italy were positive for M. fructicola (34). Therefore, future population structure changes, especially the spread of $M$. fructicola, should be managed with special attention and in accordance with all available quarantine and control measures.

\section{Acknowledgments}

The article is the result of activities within the projects III46008 and III43001 funded by the Ministry of Education, Science, and Technological Development of the Republic of Serbia and FP7-REGPOT-AREA-316004.

\section{Literature Cited}

1. Anonymous. 2004. Monilinia fructigena (brown rot). In: Crop Protection Compendium. CAB International, Wallingford, UK.

2. Balaž, J. 2000. Monilia spp. kao parazit voćaka. Biljni lekar. 2-3:155-162. (In Serbian)

3. Bosshard, E., Hilber-Bodmer, M., Scharer, H.-J., Bunter, M., and Duffy, B. 2006. First report of the quarantine brown rot pathogen Monilinia fructicola on imported stone fruits in Switzerland. Plant Dis. 90:1554.

4. Byrde, R. J. W., and Willettes, H. J. 1977. The Brown Rot Fungi of Fruit: Their Biology and Control. Pergamon Press, Oxford.

5. CABI. 2010. Crop Protection Compendium. Commonwealth Agricultural Bureau International (CABI), Wallingford, UK.

6. Côté, M. J., Tardif, M. C., and Meldrum, A. J. 2004. Identification of Monilinia fructigena, M. fructicola, M. laxa, and Monilia polystroma on inoculated and naturally infected fruit using multiplex PCR. Plant Dis. 88:1219-1225.

7. De Cal, A., Gell, I., Usall, J., Vinas, I., and Melgarejo, P. 2009. First report of brown rot caused by Monilinia fructicola in peach orchards in Ebro Valley, Spain. Plant Dis. 93:763.

8. Duchoslavová, J., Širucková, I., Zapletalová, E., Navrátil, M., and Šafárová, D. 2007. First report of brown rot caused by Monilinia fructicola on various stone and pome fruits in the Czech Republic. Plant Dis. 91:907.

9. FAOSTAT.2011. Food and Agriculture Organisation of the United Nations. Online publication. http://faostat3.fao.org/home/index.html

10. Förster, H., and Adaskaveg, J. E. 2000. Early brown rot infections in sweet cherry fruit are detected by Monilinia-specific DNA primers. Phytopathology 90:171-178.

11. Fulton, C. E., van Leeuwen, G. C. M., and Brown, A. E. 1999. Genetic variation among and within Monilinia species causing brown rot of stone and pome fruits. Eur. J. Plant Pathol. 105:495-500.

12. Gell, I., Cubero, J., and Melgarejo, P. 2007. Two different PCR approaches for universal diagnosis of brown rot and identification of Monilinia spp. in stone fruit trees. J. Appl. Microbiol. 103:2629-2637.

13. Gibert, C., Chadoeuf, J., Nicot, P., Vercambre, G., Genard, M., and Lescourret, F. 2009. Modelling the effect of cuticular crack surface area and inoculum density on the probability of nectarine fruit infection by Monilinia laxa. Plant Pathol. 58:1021-1031.
14. Harrington, T. C., and Wingfield, B. D. 1995. A PCR-based identification method for species of Armillaria. Mycologia 87:280-288.

15. Hilber-Bodmer, M., Bünter, M., and Patocchi, A. 2010. First report of brown rot caused by Monilinia fructicola on apricot in a Swiss orchard. Plant Dis. 94: 643.

16. Holb, I. J. 2006. Possibilities of brown rot management in organic stone fruit production in Hungary. Int. J. Hortic. Sci. 12:87-91.

17. Hrustić, J., Tanović, B., Mihajlović, M., Delibašić, G., Stanković, I., Krstić, B., and Bulajić, A. 2013. First report of brown rot caused by Monilinia fructicola on nectarine in Serbia. Plant Dis. 97:147.

18. Ioos, R., and Frey, P. 2000. Genomic Variation within Monilinia laxa, $M$. fructigena, and $M$. fructicola, and application to species identification by PCR. Eur. J. Plant Pathol. 106:373-378.

19. Jansch, M., Frey, J. E., Hilber-Bodmer, M., Broggini, G. A. L., Weger, J., Schnabel, G., and Patocchi, A. 2012. SSR marker analysis of Monilinia fructicola from Swiss apricots suggests introduction of the pathogen from neighbouring countries and the United States. Plant Pathol. 61:247-254.

20. Lane, C. R. 2002. A synoptic key for differentiation of Monilinia fructicola, $M$. fructigena and M. laxa, based on examination of cultural characters. Bull. OEPP/EPPO Bull. 32:489-493.

21. Ma, Z., and Michailides, T. J. 2007. Approaches for eliminating PCR inhibitors and designing PCR primers for the detection of phytopathogenic fungi. Crop Prot. 26:145-161.

22. Michailides, T. J., Luo, Y., Ma, Z., and Morgan, D. P.2007. Brown rot of dried plum in California: new insight on an old disease. APSnet Feature Story. Online publication. http://www.apsnet.org/publications/apsnetfeatures/Pages/BrownRot. aspx

23. Michailides, T. J., Ogawa, J. M., and Opgenorth, D. C. 1987. Shift of Monilinia spp. and distribution of isolates sensitive and resistant to benomyl in California prune and apricot orchards. Plant Dis. 71:893-896.

24. Miessner, S., and Stammler, G. 2010. Monilinia laxa, M. fructigena and M. fructicola: Risk estimation of resistance to QoI fungicides and identification of species with cytochrome b gene sequences. J. Plant Dis. Prot. 117: 162-167.

25. Munda, A., and Viršček Marn, M. 2010. First report of brown rot caused by Monilinia fructicola affecting peach orchards in Slovenia. Plant Dis. 94:1166.

26. Muñoz, Z., Moret, A., and Bech, J. 2008. Morphological and molecular characterization of Monilinia sp. isolates and pathogenicity on apple. Agrociencia 42:119-128.

27. Nikolić, D., Keserović, Z., Magazin, N., Paunović, S., Miletić, R., Nikolić, M. and Milivojević, J. 2012. Pages 3-22 in: Stanje i perspektive razvoja voćarstva u Srbiji. Zbornik radova i apstrakata 14. kongresa voćara i vinogradara Srbije sa međunarodnim učešćem. Vrnjačka Banja (In Serbian)

28. OEPP/EPPO. 2002. First report of Monilinia fructicola in France. EPPO Reporting Service 2002/003. Online publication. http://archives.eppo.int/ EPPOReporting/2002/Rse-0201.pdf

29. OEPP/EPPO. 2009. PQR database. European and Mediterranean Plant Protection Organization, Paris. Online publication. https://www.eppo.int DATABASES/pqr/pqr.htm

30. OEPP/EPPO. 2010. First report of Monilinia fructicola in Germany. EPPO Reporting Service 2010/016. Online publication. http://archives.eppo.int/ EPPOReporting/2010/Rse-1001.pdf

31. Ogawa, J. M., Zehr, E. I., and Bird, W. 1995. Brown rot. Pages 7-10 in Compendium of Stone Fruit Diseases. J. M. Ogawa, E. I. Zehr, G. W. Bird, D. F. Ritchie, K. Uriu, and J. K. Uyemoto, eds. American Phytopathological Society, St. Paul, MN.

32. Ondejkova, N., Hudecova, M., and Bacigalova, K. 2010. First report on Monilinia fructicola in the Slovak Republic. Plant Prot. Sci. 46:181-184.

33. Pellegrino, C., Gullino, M. L., Garibaldi, A., and Spadaro, D. 2009. First report of brown rot of stone fruit caused by Monilinia fructicola in Italy. Plant Dis. 93:668

34. Petroczy, M., and Palkovics, L. 2006. First report of brown rot caused by Monilinia fructicola on imported peach in Hungary. Plant Dis. 90:375.

35. Petróczy, M., and Palkovics, L. 2009. First report of Monilia polystroma on apple in Hungary. Eur. J. Plant Pathol. 125:343-347.

36. Petróczy, M., Szigethy, A., and Palkovics, L. 2012. Monilinia species in Hungary: morphology, culture characteristics, and molecular analysis. Trees 26:153-164.

37. Poniatowska, A., Michalecka, M., and Bielenin, A. 2013. Characteristic of Monilinia spp. fungi causing brown rot of pome and stone fruits in Poland Eur. J. Plant Pathol. 135:855-865.

38. Rungjindamai, N., Jeffries, P., and Xu, X. M. 2014. Epidemiology and management of brown rot on stone fruit caused by Monilinia laxa. Eur. J. Plant Pathol. 140:1-17

39. Sokal, R. R., and Rohlf, F. J. 1995. Biometry: The Principles and Practice of Statistics in Biological Research, 3rd ed. W. H. Freeman and Company, New York.

40. Stojanović, D., and Kostić, B. 1957. Prilog proučavanju vrsta Monilia na jabučastom i koštičavom voću. Zaštita bilja 44:69-72. (In Serbian)

41. Sződi, S. Z., Komjáti, H., and Turóczi, G. 2012. Characterization of M. laxa and $M$. fructigena isolates from Hungary with MP-PCR. Hortic. Sci. 39: 116-122.

42. Tamura, K., Peterson, D., Peterson, N., Steker, G., Nei, M., and Kumar, S 2011. MEGA5: Molecular evolutionary genetics analysis using maximum 
likelihood, evolutionary distance, and maximum parsimony methods. Mol. Biol. Evol. 28:2731-2739.

43. Thompson, J. D., Higgins, D. G., and Gibson, T. J. 1994. CLUSTAL W: Improving the sensitivity of progressive multiple sequence alignment through sequence weighting, position-specific gap penalties and weight matrix choice. Nucleic Acids Res. 22:4673-4680.

44. van Brouwershaven, I. R., Bruil, M. L., van Leeuwen, G. C. M., and Kox, L. F. F. 2010. A real-time (TaqMan) PCR assay to differentiate Monilinia fructicola from other brown rot fungi of fruit crops. Plant Pathol. 59:548-555.

45. Vasić, M., Duduk, N., and Ivanović, M. S. 2013. First report of brown rot caused by Monilia polystroma on apple in Serbia. Plant Dis. 97:145.

46. Vasić, M., Duduk, N., Ivanović, M. M., Obradović, A., and Ivanović, M. S. 2012. First report of brown rot caused by Monilia fructicola on stored apple in Serbia. Plant Dis. 96:456.
47. Villarino, M., Melgarejo, P., Usall, J., Segarra, J., and De Cal, A. 2010. Primary inoculum sources of Monilinia spp. in Spanish peach orchards and their relative importance in brown rot. Plant Dis. 94:1048-1054.

48. White, T. J., Bruns, T., Lee, S., and Taylor, J. 1990. Amplification and direct sequencing of fungal ribosomal RNA genes for phylogenetics. Pages 315-322 in: PCR Protocols. M. A. Innis, D. H. Gelfand, J. J. Sninsky, and T. J. White, eds. Academic Press, San Diego, CA.

49. Xu, X. M., and Robinson, J. D. 2000. Epidemiology of brown rot (Monilinia fructigena) on apple: infection of fruits by conidia. Plant Pathol. 49:201-206.

50. Zhu, X. Q., Chen, X. Y., and Guo, L. Y. 2011. Population structure of brown rot fungi on stone fruits in China. Plant Dis. 95:1284-1291.

51. Zhu, X. Q., and Guo, L. Y. 2010. First report of brown rot on plum caused by Monilia polystroma in China. Plant Dis. 94:478. 